\title{
ResearchArticle \\ Genetics of green pod yield in table pea (Pisum sativum L. Hort.)
}

\author{
Pallavi Pathak and S.S. Gahalain
}

\begin{abstract}
SUMMARY
An experiment consisting $45 \mathrm{~F}_{1}$ s derived from ten pea varieties/strains i.e. AP-2, AP-4, AP-5, AP-1, KS-185, KS-218, KS601, KS-701, KS-801 and AP-3, during the rabi season of 2014-15 were raised in crossing block and all possible combination excluding reciprocals were made to obtained 45 crosses. The crosses were evaluated at Vegetable Research Farm, Kalyanpur, Kanpur during Rabi of 2015-16. The analysis of variance for combining ability showed significant differences both for GCA and SCA variances. The estimated values of $\sigma^{2}$ GCA were higher than $\sigma^{2}$ SCA for number of fertile branches per plant, pod width, number of pods per plant, seed-shell ratio and protein content indicated the more contribution of additive genetic variances for controlling these characters. Higher estimates of $\sigma^{2}$ SCA than $\sigma^{2}$ GCA for green pod yield, pod length and number of seeds per pod indicated the role of non additive genes for controlling these traits. Parents AP1, AP-3, AP-4, KS-601 and KS-701 were found good general combiners for majority of the characters under study including green pod yield per plant. Cross combinations namely; AP2 x AP3, AP2 x KS801, KS218 x KS601, AP4 x AP1, KS801 x AP3, AP4 x KS701, KS185 x KS218, KS185 x KS601, KS701 x KS801 and AP4 x KS601 were the top ten crosses which showed higher mean values and significant SCA effects for green pod yield and some other characters under study. Significant contribution of non additive genes were observed for controlling the green pod yield, pod length and number of seeds per pod while additive genetic effects were found effective for controlling the expression of pod width, number of pod per plant, seed-shell ratio and protein content.
\end{abstract}

Key Words : Gene action, Green pod yield, Combining ability, GCA effect, SCA effect, Table pea Pisum sativum

How to cite this article : Pathak, Pallavi and Gahalain, S.S. (2018). Genetics of green pod yield in table pea (Pisum sativum L. Hort.). Internat. J. Plant Sci., 13 (1): 196-200, DOI: 10.15740/HAS/IJPS/13.1/196-200.

Article chronicle : Received : 10.11.2017; Revised : 12.12.2017; Accepted : 27.12.2017

MEMBERS OF THE RESEARCH FORUM

Author to be contacted :

Pallavi Pathak, S.S.J. Campus, Kumaun University, Almora (Uttarakhand)

India

Email : pathakfast@gmail.com

Address of the Co-authors:

S.S. Gahalain, S.S.J. Campus, Kumaun University, Almora (Uttarakhand) India 